
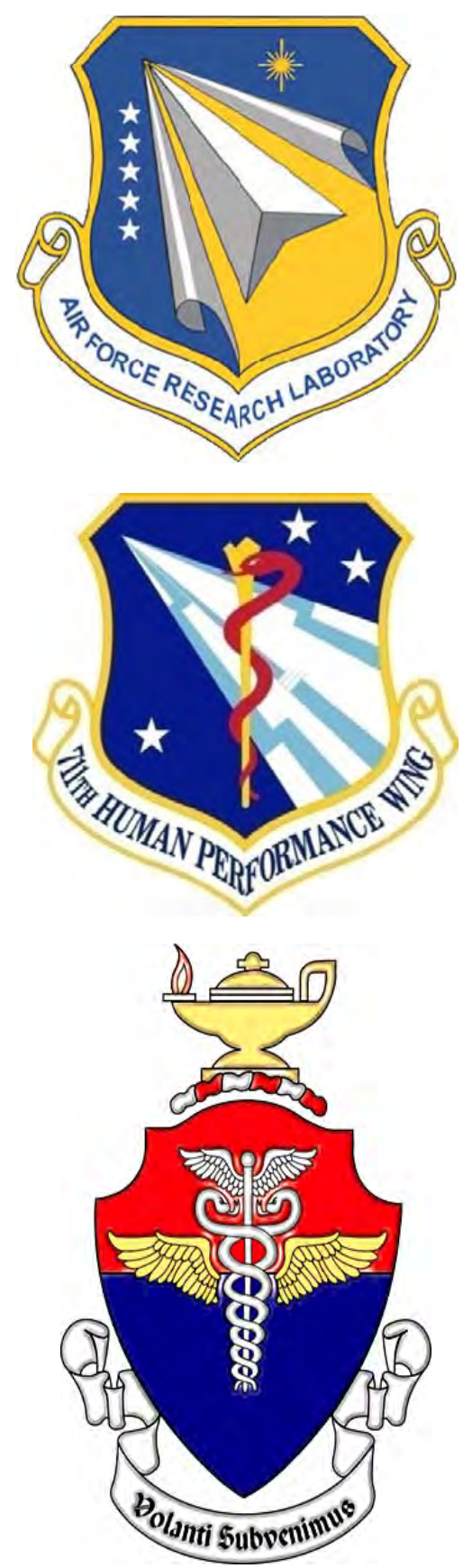

Distribution Statement A: Approved for public release; distribution is unlimited. Case Number: 88ABW-2012-0565, 7 Feb 2012

\title{
AFRL-SA-WP-SR-2012-0002
}

\section{INTERIM BASE-LEVEL GUIDE FOR EXPOSURE TO JET FUEL AND ADDITIVES}

\author{
John P. Hinz \\ Lt Col David M. Sonntag \\ Capt Brian M. Clarke
}

December 2011

Air Force Research Laboratory $7_{11}^{\text {th }}$ Human Performance Wing School of Aerospace Medicine Occupational \& Environmental Health Risk Analysis Division 2510 Fifth St. Wright-Patterson AFB, OH 45433-7913 


\section{NOTICE AND SIGNATURE PAGE}

Using Government drawings, specifications, or other data included in this document for any purpose other than Government procurement does not in any way obligate the U.S. Government. The fact that the Government formulated or supplied the drawings, specifications, or other data does not license the holder or any other person or corporation or convey any rights or permission to manufacture, use, or sell any patented invention that may relate to them.

Qualified requestors may obtain copies of this report from the Defense Technical Information Center (DTIC) (http://www.dtic.mil). PUBLICATION IN ACCORDANCE WITH ASSIGNED DISTRIBUTION STATEMENT.

//SIGNATURE//

STEVEN R. HINTEN, Col, USAF, BSC
//SIGNATURE//

MARK E. SMALLWOOD, Col, USAF, BSC

This report is published in the interest of scientific and technical information exchange, and its publication does not constitute the Government's approval or disapproval of its ideas or findings. 
Public reporting burden for this collection of information is estimated to average 1 hour per response, including the time for reviewing instructions, searching existing data sources, gathering and

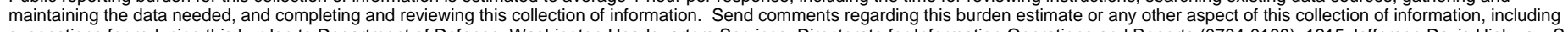

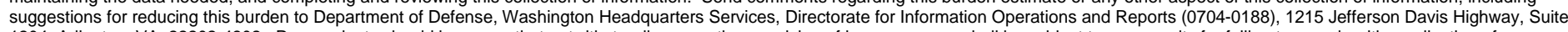
1204, Arlington, VA 22202-4302. Respondents should be aware that notwithstanding any other provision of law, no person shall be subject to any penalty for failing to comply with a collection of information if it does not display a currently valid OMB control number. PLEASE DO NOT RETURN YOUR FORM TO THE ABOVE ADDRESS.
1. REPORT DATE (DD-MM-YYYY)
$01-12-2011$

\section{REPORT TYPE}
Special Report

4. TITLE AND SUBTITLE

Interim Base-Level Guide for Exposure to Jet Fuel and Additives
3. DATES COVERED (From - To)

January 2010 - December 2011

5a. CONTRACT NUMBER

\section{AUTHOR(S)}

John P. Hinz, Lt Col David M. Sonntag, Capt Brian M. Clarke 5b. GRANT NUMBER

5c. PROGRAM ELEMENT NUMBER

5d. PROJECT NUMBER

5e. TASK NUMBER

5f. WORK UNIT NUMBER

8. PERFORMING ORGANIZATION REPORT NUMBER

AFRL-SA-WP-SR-2012-0002

10. SPONSORING/MONITOR'S ACRONYM(S)

11. SPONSOR/MONITOR'S REPORT NUMBER(S)

\section{DISTRIBUTION / AVAILABILITY STATEMENT}

Distribution Statement A: Approved for public release; distribution is unlimited. Case Number: 88ABW-2012-0565, 7 Feb 2012

\section{SUPPLEMENTARY NOTES}

\section{ABSTRACT}

This report provides interim guidance on evaluating exposures to the most common jet fuel and additives used in the U.S. Air Force, Jet Propulsion Fuel-8 (JP-8). The report is "interim" because there are a number of emerging fuels such as synthetic paraffinic kerosene and biofuels that are already approved for use on Air Force weapon systems but whose occupational and environmental exposure limits (OEELs) are not well-defined. OEELs recommended in this report for JP-8 should be sufficiently conservative to be applied to emerging fuels and their blends with JP-8. Contract efforts are currently underway to evaluate the toxicity of emerging fuels, and the U.S. School of Aerospace Medicine/Occupational \& Environmental Health Department anticipates further exposure guidance will be issued from those efforts.

15. SUBJECT TERMS

JP-8, additives, exposure monitoring

\begin{tabular}{|c|c|c|c|c|l|}
\hline \multicolumn{2}{|l|}{ 16. SECURITY CLASSIFICATION OF: } & $\begin{array}{l}\text { 17. LIMITATION } \\
\text { OF ABSTRACT }\end{array}$ & $\begin{array}{l}\text { 18. NUMBER } \\
\text { OF PAGES }\end{array}$ & $\begin{array}{l}\text { 19a. NAME OF RESPONSIBLE PERSON } \\
\text { John Hinz }\end{array}$ \\
\cline { 1 - 2 } $\begin{array}{c}\text { a. REPORT } \\
\text { U }\end{array}$ & $\begin{array}{c}\text { b. ABSTRACT } \\
\text { U }\end{array}$ & $\begin{array}{c}\text { c. THIS PAGE } \\
\text { U }\end{array}$ & SAR & 15 & $\begin{array}{l}\text { 19b. TELEPHONE NUMBER (include area } \\
\text { code) }\end{array}$ \\
\hline
\end{tabular}


This page intentionally left blank. 


\section{TABLE OF CONTENTS}

Section

Page

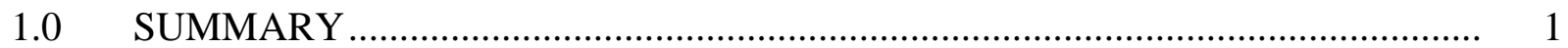

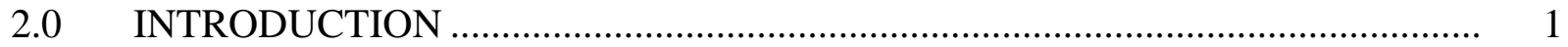

3.0 HAZARD EVALUATION ..................................................................... 1

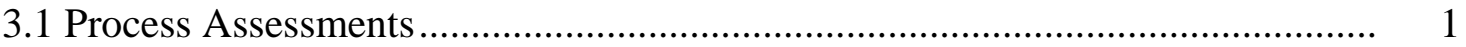

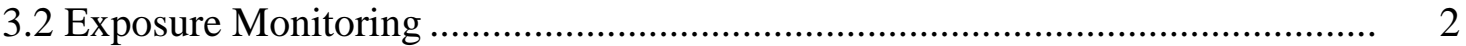

3.3 Occupational and Environmental Exposure Limits (OEELs)........................... 3

3.4 Respiratory Protection ................................................................................ 4

3.5 Protective Clothing and Equipment ............................................................ 4

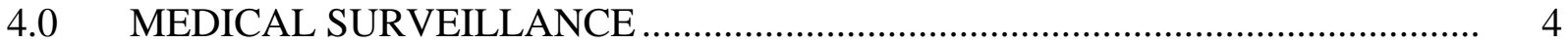

5.0 AREAS UNDER FURTHER STUDY …....................................................... 4

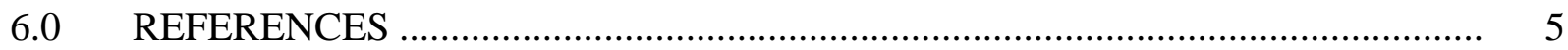

APPENDIX - OSHA Benzene Standard ..................................................................... 7

LIST OF ABBREVIATIONS AND ACRONYMS …................................................. 9 
This page intentionally left blank. 


\subsection{SUMMARY}

This report provides interim guidance on evaluating exposures to the most common jet fuel and additives used in the U.S. Air Force, Jet Propulsion Fuel-8 (JP-8). The report is "interim" because there are a number of emerging fuels such as synthetic paraffinic kerosene and biofuels that are already approved for use on Air Force weapon systems, but whose occupational and environmental exposure limits (OEELs) are not well-defined. OEELs recommended in this report for JP-8 should be sufficiently conservative to be applied to emerging fuels and their blends with JP-8. Contract efforts are currently underway to evaluate the toxicity of emerging fuels, and the U.S. Air Force School of Aerospace Medicine/Occupational \& Environmental Health Department anticipates further exposure guidance will be issued from those efforts.

\section{$2.0 \quad$ INTRODUCTION}

Jet Propulsion Fuel-8 (JP-8) is used in U.S. Air Force aircraft and support equipment. It is nearly identical to commercial aviation fuel (Jet-A), with the exception of additives used to enhance performance (Table 1). For additional information on JP-8, refer to military specification MIL-DTL-83133E (Ref 1).

Table 1. Common JP-8 Additives

\begin{tabular}{|c|c|c|}
\hline Additive & Usual Chemical Identity & Special Notes \\
\hline $\begin{array}{l}\text { Fuel-system icing } \\
\text { inhibitor }\end{array}$ & 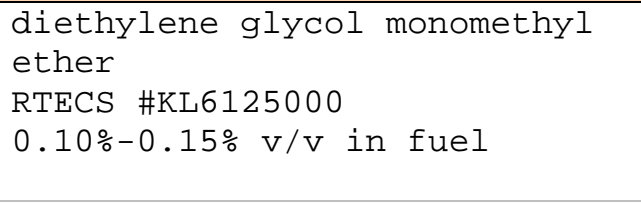 & $\begin{array}{l}\text { Reproductive toxicant } \\
\text { concentration in water } \\
\text { found in tank bottoms } \\
\text { may be as high as } 30 \%- \\
50 \% \mathrm{~V} / \mathrm{v}\end{array}$ \\
\hline Static dissipater & $\begin{array}{l}\text { Stadis } 450 \\
\text { mostly toluene, various trade- } \\
\text { secret polymeric compounds }\end{array}$ & Reproductive toxicant \\
\hline Metal deactivator & $\begin{array}{l}\mathrm{N}, \mathrm{N}^{\prime} \text { - disalycylidene-1,2- } \\
\text { propanediamine }(5.7 \mathrm{mg} / \mathrm{L}) \\
\text { RTECS \#GP313000๑ }\end{array}$ & \\
\hline Antioxidant & $\begin{array}{l}17-24 \mathrm{mg} / \mathrm{L} \text {, of any number of } \\
\text { six common alkyl phenolic } \\
\text { compounds }\end{array}$ & \\
\hline
\end{tabular}

\subsection{HAZARD EVALUATION}

\subsection{Process Assessments}

Assessments should be conducted in accordance with Air Force Instruction 48-145, Occupational and Environmental Health Program (Ref 2). Processes that involve potential exposure to JP-8 should be documented in the Defense Occupational and Environmental Health Readiness System.

The most common route of exposure to jet fuel is by skin contact. Identify any processes where workers may have the opportunity to come into contact with liquid fuel, either in aircraft or ground-based equipment, tanks, pipes, storage bowsers, and so forth. Because JP-8 has a relatively low volatility, focus on processes that could leak or drip JP-8 onto permeable clothing 
like ABUs and stay in close contact with the skin throughout the work day or be carried home to family members.

Certain processes, such as pulling foam from an aircraft fuel tank, present a high potential for skin exposure. Workers should immediately wash off any jet fuel from the skin with soap and water. Any clothing that becomes saturated with fuel should be changed. Failure to immediately wash off the fuel may result in skin irritation.

Because of strict controls normally in place for permit-required entry into confined spaces [Air Force Occupational Safety and Health (AFOSH) Standard 91-25 (Ref 3)], airborne exposures for entry into fuel tanks are usually well controlled. Engine start operations under low ambient temperature conditions can produce large amounts of uncombusted and aerosolized fuel. Pay close attention not only to ground crew who may work around cold-start areas but also to potential downwind populations. Clouds or mists coming from turbine exhaust in cold settings may not be steam - the cloud could actually be aerosolized fuel.

Special consideration should be given to areas where water collects and settles to the bottom of fuel tanks. Water in fuel tanks presents several potential hazards. The first is that deicing compounds in JP-8 are designed to preferentially partition into the water phase and lower its freezing point. This means that concentrations of deicer in water found at the bottoms of fuel tanks could be as high as $30 \%-50 \%$ on a volume basis. This would present primarily a skin contact hazard to personnel involved in fuel drainage or sumping operations or at oil-water separators.

The presence of water anywhere in fuel systems also creates an environment ripe for microbial growth. Because the microbes that grow in fuel tank bottoms may include potential human pathogens (Ref 4), the health hazards of colonized fuel would be similar to those for workers who are exposed to wastewater or sewage. Workers who have potential contact with colonized fuel samples or tank sediments should be identified to the Occupational and Environmental Health Working Group (OEHWG) so that their immune status and potential for exposure to reproductive toxicants found in JP-8 can be determined.

Microbial growth in fuel sumps can be identified visually by the presence of a slimy biofilm that floats at the fuel-water interface or by fuel that is not clear and bright or that has a sour odor. Operational concerns can arise from the ability of biofilms to foul and plug fuel lines, leading to engine starvation. Colonized fuel can also "infect” previously uncontaminated fuel through the use of common bowsers or storage tanks. Bioenvironmental engineering expertise in drinking water and wastewater management can help the logistics community to identify areas for potential cross-contamination of fuel. Diagnostics tests (such as quantitative real-time polymerase chain reaction) for detecting microbial growth in fuel are currently under development by the Air Force Research Laboratory (AFRL/RZPF). The potential health hazards of microbial growth in fuels is a complex and emerging issue. If you have questions about microbial growth in fuels, please contact the U.S. Air Force School of Aerospace Medicine (USAFSAM) Environmental, Safety, and Occupational Health (ESOH) Service Center (DSN 798-3764, 1-888-232-ESOH (3764), or esoh.service.center@wpafb.af.mil).

\subsection{Exposure Monitoring}

Airborne exposures to JP-8 vary widely over time and activity and are also influenced by climate and different refinery blends. A broad survey of Air Force personnel has characterized tasks with the highest potential for airborne exposures (Ref 5). The highest exposures occur 
inside poorly ventilated hangars and involve tasks related to fuel tank-entry, tank-entry attendant/runner/fireguard, and leak detection. Cold engine startups in any area can produce significant aerosol exposures to uncombusted fuel. Vapor sampling for JP-8 on the flight line is generally not warranted.

To sample for JP-8 vapor exposure, use the National Institute for Occupational Safety and Health (NIOSH) Method 1550, "Naphthas." Submit a bulk sample (5 mL) along with the air sample for best results. For screening samples, direct-reading instruments can be used.

PERMEA-TEC ${ }^{\mathrm{TM}}$ pads (SKC, Eighty Four, PA) may be used to help monitor for and protect against skin contact from personal protective equipment (PPE) failure or breakthrough. The benzene concentration in JP-8 is typically very low (less than $0.05 \%$ ) and is at least 10 times less than the benzene concentration in JP-4. However, the benzene content of JP-8 can vary widely depending on the supplier and aging conditions of the fuel. Operations to remove firesuppressant foam have historically resulted in the highest airborne benzene exposures from JP-8. Career fields with the potential for exposure to benzene include those involved in fuel handling and distribution along with those involved with fuel and aircraft systems maintenance, especially Air Force Specialty Codes 2A64x4, 2A6x1, 2A3x3, 2A5x1, 3E4xC1, and 2F0X2.

To sample for airborne benzene, NIOSH Method 1501 for aromatic hydrocarbons should be used. If airborne exposure levels to benzene exceed 1 ppm [8-h time-weighted average (TWA)], the Occupational Safety and Health Administration (OSHA) benzene standard, Code of Federal Regulations (CFR) Title 29, Part 1910.1028, has specific requirements for establishing regulated areas and periodic workplace sampling protocols (see Appendix) (Ref 6). OSHA's Sampling and Analytical Methods: Benzene provides additional guidance (Ref 7).

\subsection{Occupational and Environmental Exposure Limits (OEELs)}

Since Air Force Manual 48-155 superseded AFOSH Standard 48-8, a legal or peerreviewed occupational and environmental exposure limit (OEEL) for jet fuel has not been available. Based on a National Research Council (NRC) study contracted by the Air Force, USAFSAM currently suggests using $200 \mathrm{mg} / \mathrm{m}^{3}$ (8-h TWA) for JP-8 vapor and $5 \mathrm{mg} / \mathrm{m}^{3}$ (8-h TWA) for aerosol as interim OEELs (Ref 8). Augmenting the NRC's study, additional in-depth and up-to-date toxicity, mode of action, health, and exposure guidance on JP-5 and 8 can also be found in the National Advisory Committee on Acute Exposure Guideline Levels document, “Jet Propellant Fuels 5 and 8 Acute Exposure Guideline Levels” (see Ref 9).

Routine sampling to characterize airborne exposure to JP-8 should normally focus on vapor-phase. The main area where aerosol sampling may be warranted would be in cold engine start operations, where as much as $30 \%-40 \%$ of fuel leaving the engine is uncombusted. For most operations, vapor sampling should be sufficiently conservative. However, if you identify a need to perform aerosol sampling for JP-8, please contact the USAFSAM-ESOH Service Center.

Additionally, because of the adoption of new synthetic versions of JP-8, such as synthetic paraffinic kerosene (SPK), these new blends have no OEEL yet established. USAFSAM suggests using this interim guidance until the data gaps outlined in section 5.0 of this report have been addressed. The best current data suggest existing JP-8 OEELs are more conservative than those that might be derived from initial studies of JP-8/SPK blend toxicity studies.

As previously noted, the benzene content of JP-8 is typically low - median values for military fuel maintenance workers are $78 \mathrm{ppb}$ and median values for military fuel handling/distribution/recovery/testing workers are 2 ppb (Ref 10). Nevertheless, for purposes of 
safety and compliance with current OSHA guidance wherever monitoring for benzene is warranted, the most current OSHA standards apply.

\subsection{Respiratory Protection}

Respirators shall be worn, as directed by the base Bioenvironmental Engineering office, in accordance with AFOSH Standard 48-137, Respiratory Protection Program (Ref 11).

\subsection{Protective Clothing and Equipment}

Personnel who may come into contact with JP-8 should wear appropriate PPE (e.g., butyl and nitrile rubber gloves, neoprene rubber headwear/footwear, coveralls). Personnel who have prolonged, direct contact with JP-8 (e.g., fuel cell workers) must wear a tri-layer coverall, including bootie [see Technical Order 1-1-3 (Ref 12)]. This coverall is a tri-layer, anti-static laminate consisting of a nylon filament face, a Teflon ${ }^{\circledR} /$ Gore-Tex ${ }^{\circledR}$ membrane, and nylon knit with anti-static filaments incorporated into the fabric structure. To protect against leaks, joints between the tri-layer coverall and boots and gloves should be secured with elastic bands, tape, or other means. For details on permit-required confined space entry procedures and PPE, see AFOSH Standard 91-25 (Ref 3).

\subsection{MEDICAL SURVEILLANCE}

These recommendations apply to any worker who is exposed above the action level of JP-8 $\left(100 \mathrm{mg} / \mathrm{m}^{3}\right)$ or who has a significant dermal exposure to jet fuel. Significant exposures include those tasks in which a worker comes into prolonged contact with jet fuel on a routine basis (e.g., fuel cell worker). The initial and annual medical surveillance should include a health history and physical exam. The health history should focus on pulmonary, dermal, neurologic, renal, and hepatic systems. The physical exam should focus on the skin. Special note should be made of potential for contact with water and sediments found in the bottom of fuel tanks, as outlined in section 3.1. Additional medical surveillance activities may be approved by the base OEHWG based on unique mission requirements or exposures.

\subsection{AREAS UNDER FURTHER STUDY}

USAFSAM has developed problem statements for JP-8 health risk assessment that are currently under study. These include:

- Microbial growth in fuels

- Further toxicological characterization of SPK-blended fuel vapors and aerosols

- Methods of exposure assessments to aerosolized JP-8

- Lack of OEELs for SPK or other JP-8 variants

- Absence of Air Force-specified methods for measuring atmospheric exposure concentration of JP-8/SPK blends 


\subsection{REFERENCES}

1. Aeronautical Systems Center, Turbine Fuels, Aviation, Kerosene Types, NATO F-34 (JP-8), NATO F-35, and JP-8+100, MIL-DTL-83133E, Aeronautical Systems Center, WrightPatterson AFB, OH, 1 Apr 1999, URL: http://www.wbdg.org/ccb/FEDMIL/dtl83133e.pdf. Accessed 26 Oct 2011.

2. U.S. Air Force, Occupational and Environmental Health Program, Air Force Instruction 48145, Department of the Air Force, Washington, DC, 15 Sep 2011, URL: http://www.epublishing.af.mil/shared/media/epubs/AFI48-145.pdf. Accessed 26 Oct 2011.

3. U.S. Air Force, Safety, Confined Spaces, Air Force Occupational Safety and Health Standard 91-25, Department of the Air Force, Washington, DC, 1 Feb 2008, URL: http://www.epublishing.af.mil/shared/media/epubs/AFOSHSTD91-25.pdf. Accessed 26 Oct 2011.

4. Rauch ME, Graef HW, Rozenzhak SM, Jones SE, Bleckmann CA, Kruger RL, et al., "Characterization of Microbial Contamination in United States Air Force Aviation Fuel Tanks,” Journal of Industrial Microbiology \& Biotechnology, 33(1), Jan 2006, pp. 29-36

5. Smith KW, Proctor SP, Ozonoff A, McClean MD, "Inhalation Exposure to Jet Fuel (JP8) Among U.S. Air Force Personnel,” Journal of Occupational and Environmental Hygiene, 7(10), 2010, pp. 563-72.

6. National Archives and Records Administration, "Benzene," in Code of Federal Regulations, Title 29, Part 1910.1028, 19 Dec 2011, URL: http://ecfr.gpoaccess.gov/cgi/t/text/textidx? $\mathrm{c}=\mathrm{ecfr} \& \operatorname{sid}=75159 \mathrm{~b} 2442 \mathrm{~d} 4746 \mathrm{c} 855 \mathrm{fa} 943 \mathrm{f} 5 \mathrm{ee} 4 \mathrm{e} 01 \& \mathrm{rgn}=\mathrm{div} 8 \& \mathrm{view}=\mathrm{text} \&$ node=29:6.1. 1.1.1.1.1.24\&idno=29. Accessed 26 Oct 2011.

7. Occupational Safety and Health Administration, Sampling and Analytical Methods: Benzene, Sep 2002, URL: http://www.osha.gov/dts/sltc/methods/validated/1005/1005.html. Accessed 9 Dec 2011.

8. Subcommittee on Jet-Propulsion Fuel 8, Committee on Toxicology, National Research Council, Toxicologic Assessment of Jet-Propulsion Fuel 8, The National Academies Press, Washington, DC, 2003.

9. Committee on Acute Exposure Guideline Levels, Committee on Toxicology, Board on Environmental Studies and Toxicology, Division on Earth and Life Studies, National Research Council, "Jet Propellant Fuels 5 and 8 Acute Exposure Guideline Levels," in Acute Exposure Guideline Levels for Selected Airborne Chemicals: Volume 10, The National Academies Press, Washington, DC, 2011, pp. 72-139.

10. Capleton AC, Levy LS, "An Overview of Occupational Benzene Exposures and Occupational Exposure Limits in Europe and North America," Chemico-Biological Interactions, 153-154, 30 May 2005, pp. 43-53. 
11. U.S. Air Force, Respiratory Protection Program, Air Force Occupational Safety and Health Standard 48-137_IC2, Department of the Air Force, Washington, DC, 7 Apr 2009, URL: http://www.e-publishing.af.mil/shared/media/epubs/AFOSHSTD48-137.pdf. Accessed 26 Oct 2011.

12. U.S. Air Force. Technical Manual: Inspection and Repair of Aircraft Integral Tanks and Fuel Cells, TO 1-1-3, Robins AFB, GA, 25 Aug 2011, URL:

http://www.robins.af.mil/shared/media/document/AFD-091006-027.pdf. 


\title{
APPENDIX
}

\section{OSHA Benzene Standard}

\author{
Benzene 29 CFR $\$ 1910.1028$
}

Scope: Applies to all occupational exposures to benzene except:

1. Storage, transportation, distribution, dispensing, sale, or use of gasoline, motor fuels, or other fuels containing benzene subsequent to its final discharge from bulk wholesale storage facilities. Exception: The requirements do apply where gasoline or motor fuels are dispensed for more than 4 hours per day in an indoor location.

2. Loading and unloading operations at bulk wholesale storage facilities that use vapor control systems for all loading and unloading operations.

3. Storage, transportation, distribution, or sale of benzene or liquid mixtures containing more than $0.1 \%$ benzene in intact containers or in transportation pipelines sealed so they contain benzene vapors or liquids.

Exception to both 2 and 3: Hazard communication requirements in $\$ 1910.1200$ and emergency requirements in $\$ 1910.1028(\mathrm{~g})$ and $(\mathrm{i})(4)$ do apply to both of these types of operations.

4. Containers and pipelines carrying mixtures with less than $0.1 \%$ benzene.

5. Work where the only exposure to benzene is from liquid mixtures containing $0.1 \%$ or less of benzene by volume.

Initial Determination

Breathing zone air samples (taken after 12/10/1986) representing the 8-hour TWA and the15-minute exposures of employee(s) in each work area, each job classification, and each work shift (unless it can be documented that one shift will consistently have the highest exposure; then only one shift must be sampled).

Note: Objective data may be used only to determine where short-term exposure limit monitoring is needed.

Notification of employees [\$1910.1028(e)(7)] within 15 "working days" after receipt of results. Records of exposure measurements complying with $\$ 1910.1028(\mathrm{k})(1)$ must be maintained for at least 30 years.

\begin{tabular}{|c|c|c|c|}
\hline Any exposure level & Level > AL $(0.5 \mathrm{ppm})^{\mathrm{a}}$ & Level > PEL-TWA $(1 \mathrm{ppm})^{\mathrm{a}}$ & Level > STEL $(5 \mathrm{ppm})^{\mathrm{a}}$ \\
\hline$\nabla$ & $\nabla$ & $\nabla$ & $\boldsymbol{\nabla}$ \\
\hline $\begin{array}{l}\text { Monitoring for the } \\
\text { STEL must be "repeated } \\
\text { as necessary to } \\
\text { evaluate ... short- } \\
\text { term exposures" } \\
\text { - Monitoring must be } \\
\text { initiated if changes } \\
\text { might result in } \\
\text { exposure > TWA or > } \\
\text { STEL, or if there is } \\
\text { reason to suspect } \\
\text { exposure may be > TWA } \\
\text { or > STEL }\end{array}$ & $\begin{array}{l}\text { Periodic monitoring at } \\
\text { least every } 12 \text { months } \\
\text { Notification of } \\
\text { Employees } \\
\text { [\$1910.1028 (d)( } 7)] \\
\text { within } 15 \text { "working } \\
\text { days" of results } \\
\text { - Monitoring may cease } \\
\text { for employees } \\
\text { represented by the } \\
\text { monitoring if results } \\
\text { are (AL (see } \\
\text { requirements under "Any } \\
\text { exposure level") }\end{array}$ & $\begin{array}{l}\text { Periodic monitoring at } \\
\text { least every } 6 \text { months } \\
\text { Notification of } \\
\text { Employees } \\
\text { [\$1910.1028(d)(7)] } \\
\text { within } 15 \text { "working days" } \\
\text { of results } \\
\text { - Monitoring may cease } \\
\text { for employees } \\
\text { represented by the } \\
\text { monitoring if results } \\
\text { are < AL (see } \\
\text { requirements under "Any } \\
\text { exposure level") }\end{array}$ & $\begin{array}{l}\text { No periodic } \\
\text { monitoring } \\
\text { specified; however, } \\
\text { monitoring for the } \\
\text { STEL must be } \\
\text { "repeated as } \\
\text { necessary to } \\
\text { evaluate ... short- } \\
\text { term exposures" }\end{array}$ \\
\hline $\begin{array}{l}\text { Protective clothing } \\
\text { and equipment must be } \\
\text { worn where needed to } \\
\text { prevent eye contact } \\
\text { and/or skin exposure } \\
\text { to liquid }\end{array}$ & & $\begin{array}{l}\text { Methods of compliance: If } \\
\text { or work practice controls } \\
\text { TWA/STEL. Where documente } \\
\text { days/year, engineering or } \\
\text { controls must reduce TWA } \\
\text { feasible. } \\
\text { A written compliance prog } \\
\text { for implementing these co } \\
\text { Regulated areas must limi } \\
\text { protected employees, with } \\
\S 1910.1028(j)(1) \text {. } \\
\text { Respirators must be used } \\
\text { the TWA and/or the STEL a } \\
\text { A respirator program must } \\
\text { \$1910.134(b)-(d), [exce } \\
\text { (d)(3)(iii)(B)(1)\& (2)] a } \\
\text { Respirator selection must } \\
\text { requirements in Table } 1 \text { o } \\
\$ 1910.1028(g) \text {. }\end{array}$ & $\begin{array}{l}\text { feasible, engineering } \\
\text { must reduce levels }< \\
\text { exposures occur }<30 \\
\text { work practice } \\
10 \text { ppm, where } \\
\text { am must be developed } \\
\text { trols. } \\
\text { access to authorized } \\
\text { signs complying with } \\
\text { hen exposures exceed } \\
\text { d for emergencies. } \\
\text { comply with } \\
t \text { (d) (1) (iii), } \\
\text { d (f) - (m). } \\
\text { meet the minimum } \\
29 \text { CFR }\end{array}$ \\
\hline
\end{tabular}




\section{LIST OF ABBREVIATIONS AND ACRONYMS}

AFOSH Air Force Occupational Safety and Health

AL action level

CFR Code of Federal Regulations

ESOH Environmental, Safety, and Occupational Health

JP jet propulsion

NIOSH National Institute for Occupational Safety and Health

NRC National Research Council

OEEL occupational and environmental exposure limit

OEHWG Occupational and Environmental Health Working Group

OSHA Occupational Safety and Health Administration

PEL permissible exposure limit

PPE personal protective equipment

SPK synthetic paraffinic kerosene

STEL short-term exposure limit

TWA time-weighted average

USAFSAM United States Air Force School of Aerospace Medicine 